\title{
Innovations and Fighting Global Economic Problems
}

\author{
Natalia G. Vovchenko', Olga B. Ivanova', Elena D. Kostoglodova', Marina O. Otrishko', Olga S. Dzhu'
}

ABSTRACT

KEY WORDS:

JEL Classification: F630, 0110

\begin{abstract}
The authors proffer the hypothesis that the most important issue in all of the previously studied global economic problems is the imperfection of the production process. Innovations stimulate the improvement of the production process and provide solutions to global economic problems. Thus, the purpose of this article is to verify this hypothesis and determine the role of innovations in overcoming global economic problems. To verify the hypothesis, the authors use analysis of causal connections, problem and systemic analysis, economic and mathematical modeling, and a developed proprietary economic and mathematical model of the production process. The authors conduct an analysis of global economic problems at present and in perspective and determine the role of innovations in overcoming these global economic problems. The offered hypothesis is proven, and it is substantiated, based on the problem of resource limitations, disproportions of economic growth, and crises in the global economy, that innovations play an important role in solving global economic problems. For example, innovations lead to improvements in the production process because the consumption of resources is reduced and the volume of manufactured goods is increased, which solves the problem of resource limitations. Furthermore, the implementation of production innovations in enterprises in the least developed countries stimulates their economic development and reduces the level of countries' differentiation in the global economy. Accordingly, the authors determine the directions of development with respect to the innovation activities of modern enterprises for overcoming global economic problems, and they develop an algorithm for the development of the modern global economy.
\end{abstract}

innovations, global economic problems, global economy, crisis, limitations of resources

${ }^{1}$ Rostov State Economic University, Russia

\section{Introduction}

The globalization of the world economy stimulates the expansion and unification of the goals and interests of various countries with respect to the creation of a world economy. In the new millennium, humankind

\section{-}

Correspondence concerning this article should be addressed to: Natalia G. Vovchenko, Department of Finance, Rostov State Economic University (RINH), 69 Bolshaya Sadovaya St. Rostov-on-Don 344007 Russian Federation. E-mail: natalia-vovchenk@rambler.ru faces a global problem that influences each member of the global economy, and thus, it can be solved only by the joint efforts of the global community. There are several important global economic problems.

- The problem of limited resources for the manufacturing of necessary goods. This extends from the interactions between humankind and the environment and includes issues such as the lack of natural resources, the impossibility to satisfy the demand for human resources (famine, disease, etc.), the depletion of nat- 
ural resources, and the worsening of the global ecological situation. The problem of the differentiation of countries in the global economy with respect to their level of economic development is deeply rooted in the formation of the modern global economy and is exemplified by the superiority of some countries over others; this problem stems from issues of post-war development in the global economy and is manifested in the presence of the most economically developed countries, which are leaders in the global economy, and underdeveloped countries, which are actually referred to as developing countries as they strive to overcome the developed countries;

- The problem of the cyclic development of the global economy, which contributes to the aptness of an economy for crises. The market model of the economy in most countries of the world stimulates the emergence of periodic failures, which, having emerged in one country, are distributed to all countries of the world under the influence of globalization processes and under conditions of close cooperation and strong interdependence of economies.

These problems determine the outline of the modern global economy and the limitations of its further development. There is a high level of interest in this study because of these problems and the causal connections to their development, the search for the methods and means to solve them, and role of various factors in overcoming them.

The authors offer the hypothesis that the most important cause of all of the studied global economic problems is the imperfection of the production process. Innovations stimulate the perfection of the production process and ensure the solving of the global economic problems. The purpose of the article is to verify the offered hypothesis and determine possibilities and perspectives to overcome these global economic problems through the development of innovations. The achievement of this goal supposes the following successive solutions to the main problems:

- analyze the causes of the global economic problems;

- determine the possibilities to solve these problems by implementing innovations in production;

- examine the key barriers to the implementation of innovations in production in developing countries using modern Russia as an example;
- determine the perspective directions for the development of innovative activity of modern enterprises to overcome the global economic problems and develop the mechanism for the innovational development of the modern global economy.

\section{Literature review}

Global economic problems are examined in a number of studies by modern researchers. At present, there are many hypotheses as to the reasons for the emergence of these problems and the factors that allow them to be overcome. These issues are examined in the works of such authors as (Grigoreva, 2015; Gubaidullina, 2015; Melnik, Orlov, Bondarenko, Melnik, \& Grekova, 2015; Yegireddy, Panda, Rout, \& Bonthu, 2015). The most important reasons for the emergence of global economic problems include the irrational spending of resources (Omelchenko, 2015), the active development of industry (Gerards, 2015), and the irresponsible attitude towards issues of environmental protection.

The problem of limited resources is one of the most ancient of economic problems and is the reason for the emergence of economics as a science aimed at the search for a solution to this problem. It is studied in works of such authors as (Pogodaeva, Zhaparova, Rudenko, \& Skripnuk, 2015; Waisová, 2013). Despite the fact that resources are either renewable or non-renewable, they should be spent effectively due to their strict limitations (Visser, Ohan, \& Enns, 2015).

The problems of disproportionate economic growth and the differentiation in the levels of economic development of various countries in the global economy have only recently been actualized, but they have already attracted attention and become the basis for multiple lines of research, among which are the works of (Bhanumurthy \& Singh, 2013; Bozkurt, Erdem, Ero冈lu, \& 2015; Caporale \& Spagnolo, 2012; Gehringer, 2014; Jahfer \& Inoue, 2014). Due to the uniqueness of these economic systems, their economic development assumes various directions at different rates ( $\mathrm{Al}$ Mamun \& Sohag, 2015), which causes the problem of disproportionate economic growth in the global economy (Popkova, Zubakova, Bogdanov, Yakovleva, \& Nebesnay, 2013). This problem can be solved by reducing the rates of development of the leading countries 
or by quickening the rates of economic development in underdeveloped countries (Popkova, Yurev, Stepicheva, \& Denisov, 2015).

The problem of the cyclic character of development of the global economy, which is built on the basis of the market principle and is subject to the periodic emergence of global crises, became the foundation of the well-known studies of N. Kondratyev, which, having not lost their sense of reality, are reconsidered in the works of Grinin, Devezas, and Korotayev (2012) and such researchers as (Aytaç, Rankin, \& İbikoğlu, 2015; Guttmann, 2015; Heinrich, Kobayashi, \& Bryant, 2016; McMaster, 2015; Rodriguez, Turmo, \& Vara, 2014; Zhao, Jiang, \& Li, 2015).

Due to the spontaneity and unpredictability of market processes in the modern global economy, crisis phenomena emerge from time to time (Galbraith, 2015) and are then succeeded by economic growth (Capello, Caragliu, \& Fratesi, 2015). It should be noted that after a crisis, the economy usually realizes higher rates and levels of development (Hieronymi, 2016).

The role and significance of innovations in the development and production of specific enterprises, countries, and the modern global economy on the whole, the possibilities and perspectives of further innovational development of the global economy, and the transition of various countries to an innovational path of economic development are analyzed in the works of such scientists as (Coccia, 2015; Donate, Peña, \& Sánchez de Pablo, 2016; Kolychev \& Prokhorov, 2015; Rumyantsev, 2014; Vasin \& Gamidullaeva, 2015). The implementation of innovations requires a high level of development in science and education (Ng, Kanagasundram, Wong, \& Chandran, 2015); financing science and education may allow the underdeveloped countries to close the gap between themselves and the developed economies (Filinova, Filinov, Pogodina, Lunev, \& Luneva, 2015).

The most important problems associated with transitioning to innovational paths of development in various countries include traditional thinking, unfavorable business climates, and lack of investment resources (Turriago-Hoyos, Thoene, Bernal-Torres, \& AlfonsoLizarazo, 2015). Despite the popularity, research, multiple hypotheses, and extensive elaboration on the topic of global economic development, scientists have not yet come to a unified opinion as to the reasons for the emergence of global economic problems and have not yet found the means to resolve them, either separately or as a whole, even with the help of universal instrumentarium.

Thus, it is necessary to conduct further research and to offer new hypotheses. This article is devoted to the development of the topic of global economic problems and the verification of the hypothesis that the problems can be solved by increasing the innovational activities of modern enterprises.

\section{Method}

To verify the offered hypothesis, the authors adopt the method of analysis of causal connections, the method of problem and systemic analysis, and the method of economic and mathematical modeling. According to the authors of this research, economic and mathematical modeling of the production process takes the following form:

$\mathrm{PP}=(\mathrm{HR}+\mathrm{MR}+\mathrm{CR})^{*} \mathrm{TP}$

where PP - production process;

HR - human resources;

MR - material resources;

$\mathrm{CR}$ - capital resources;

TP - technology of production.

Though this is not a model of production factors, there is a certain similarity in that the production process model includes all of the main factors except entrepreneurial capability because the entrepreneur does not participate directly in the production process, but rather only organizes it.

Formula (1) indicates that the spending of resources is predetermined by the technology of production, where human resources are the investing of human labor in the production of goods and material resources are raw materials used in production.

Capital resources reflect the financial facets and include investments in production. The technology of production, which includes the production of equipment, determines the manner in which the various resources can be combined to enhance the speed of the production of goods (time spent). The authors also use systemic and problem analysis, analysis of causal connections, synthesis, induction, deduction, and formalization. 


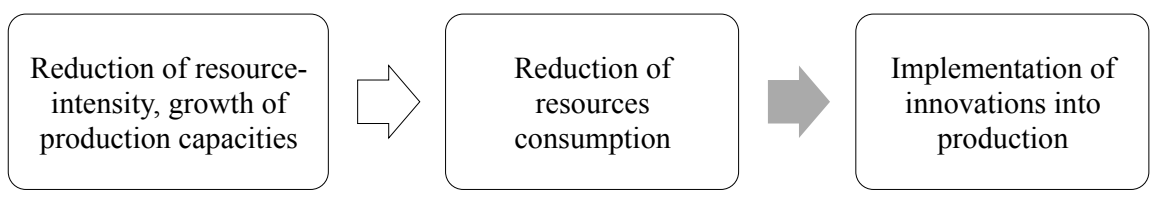

Figure 1. Process of solving the problem of limited resources in the global economy with the help of implementation of innovations into production

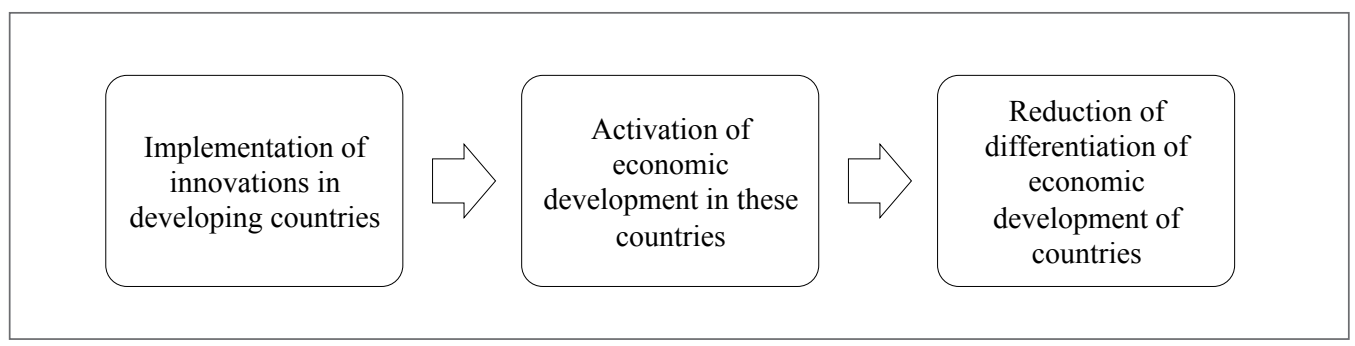

Figure 2. Process of solving the problem of disproportions of economic development of countries in the global economy with the help of implementation of innovations into production

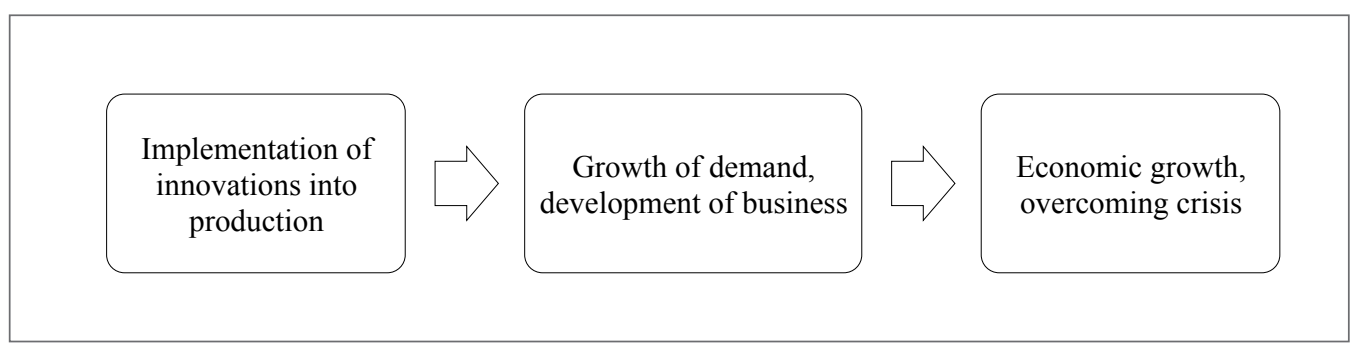

Figure 3. The process of solving the problem of crisis phenomena in the global economy by implementing innovations in production

\section{Results}

A deep and thorough study conducted to analyze the causes of global economic problems reveals that the most important cause of all studied global economic problems is imperfection in the production process. Thus, the problem of limited resources is caused, on the one hand, by the limitations in natural inheritance, which are within the control of humankind, and the peculiarities of the environment, and on the other hand, by the high resource intensity associated with modern production.
The cause of differentiation among countries regarding the level of economic development is based on the of different levels of GDP due to varied levels of production development among them. Furthermore, the cyclic development of the global economy and its aptitude to manage crises is manifested in the reduction of the rates of economic growth, which in turn are determined by the development of production.

The possibility to solve these problems is found in the implementation of innovations in production. 


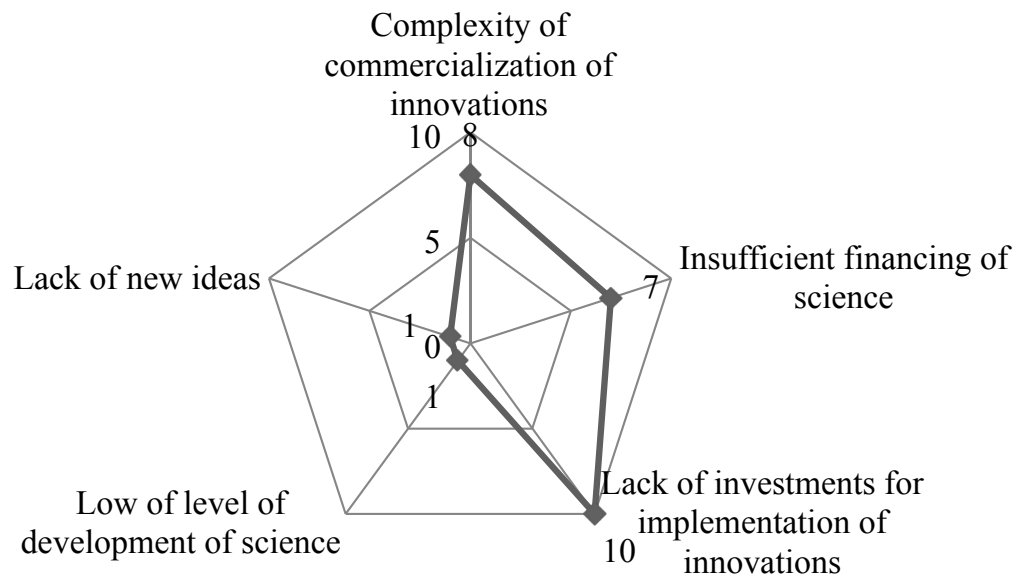

Figure 4. Key barriers on the way for implementation of innovations into production in Russia, 2014 Adapted from "Scientific research and innovations. Russia in numbers. 2015", by Rosstat (2015). Retrieved from http:// www.gks.ru/free_doc/doc_2016/rusfig/rus16.pdf

Therefore, it is necessary to examine the production processes before and after the implementation of innovations. During the initial use of technology in the production process, production factors are used and combined, which leads to a certain set of goods.

It is impossible to reduce the resource intensity of production and increase production capacities without changing production technologies. Consider, for example, the invention and implementation of the conveyor, a significant innovation that changed the production process at the beginning of the $20^{\text {th }}$ century.

As a result of the creation and implementation of innovations in production in the short-term, there is an improvement in production technology as well as a growth in the expenditures of capital resources, as the modernization of equipment requires significant resources.

However, the expenses with respect to human resources are reduced significantly due to the automatization of production. Moreover, expenditures for material resources (raw materials) are also reduced due to the implementation of technology in production.

For example, as a result of the use of the conveyor technology, there was a significant reduction in hu- man resources and a moderate reduction in expenses related to material resources. It is noted, however, that the reduction in spending for material resources may not have been a direct consequence of the invention of the conveyor, but it may be the result of the implementation of other innovations. This example reflects the implementation of innovation in production.

The spending of capital resources increased significantly due to the need to attract huge investments to modernize equipment, and production technology developed considerably. As a result, the volume of manufactured goods increased significantly, thus resolving the problem of a lack of goods and helping to meet the needs of society by, for example, reducing famine and providing drinking water and medicine.

In the long term, after the successful implementation of innovations, investments are returned and the spending of capital resources is reduced due to the decreased need for labor and material resources. Furthermore, as a result of the implementation of innovations, there is a reduction in the resource intensity of production and an increase in production capacities, thus substantiating the premise that the primary role of innovation is to solve the global economic problem of limited resources (Fig. 1). The implementation of in- 


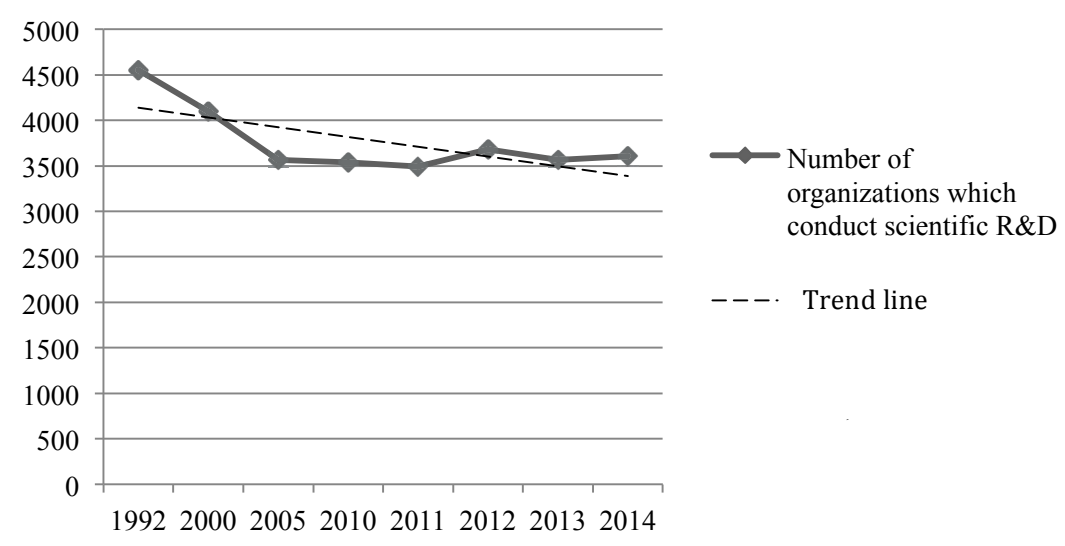

Figure 5. Dynamics of the number of innovational enterprises in Russia in 1992-2014 Adapted from "Scientific research and innovations. Russia in numbers. 2015", by Rosstat (2015). Retrieved from http:// www.gks.ru/free_doc/doc_2016/rusfig/rus16.pdf

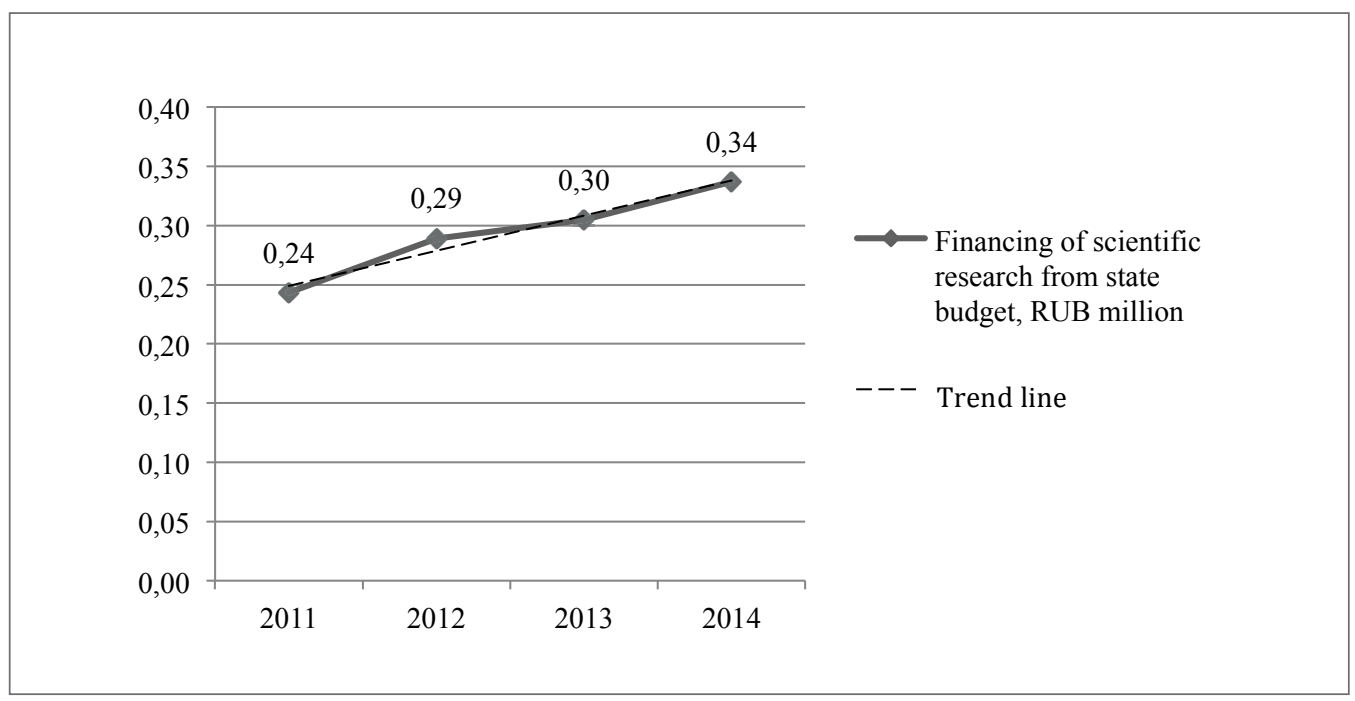

Figure 6. Dynamics of the share of spending for financing of science in the structure of Russian GDP in 2011-2014 Adapted from "Scientific research and innovations. Russia in numbers. 2015", by Rosstat (2015). Retrieved from http:// www.gks.ru/free_doc/doc_2016/rusfig/rus16.pdf

novations in the least developed countries stimulates the development of production in these countries and increases their GDP. As a result, active economic development of these countries occurs, which leads to a reduction in the level of differentiation among the countries and thus contributes to solving the problem of disproportionate economic growth in the global economy (Fig. 2). Enterprises that manufacture in- 


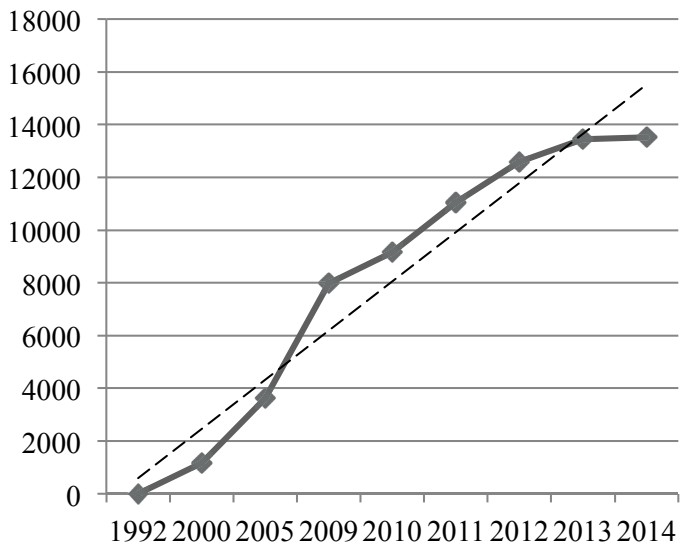

$\longrightarrow$ Investments into implementation of innovations, RUB billion

\section{--- Trend line}

Figure 7. Dynamics of investments into implementation of innovations in Russia in 1992-2014

Adapted from "Scientific research and innovations. Russia in numbers. 2015", by Rosstat (2015). Retrieved from http:// www.gks.ru/free_doc/doc_2016/rusfig/rus16.pdf

novational products have advantages when compared to other companies, as they put less expensive, better, or completely new products on the market that are in greater demand - due to the above reasons - than the products of other enterprises.

Furthermore, these innovations are adopted by other enterprises, which results in increased demand and business, even under conditions of a decline in the population's income and, correspondingly, a reduction in purchasing power.

As a result, profits grow, which leads to revenues for the state budget. These revenues then create possibilities for the further stimulation of economic development. Thus, the consequences of the crisis are overcome, and the global economy is able to overcome the recession (Fig. 3).

We consider the key barriers to the implementation of innovations in production in developing countries from the perspective modern Russia. The obstacles on the path to the development of innovations in developing countries are, as a rule, the lack of financing for science; the complexity of the commercialization of innovations; the lack of investments, which are needed to implement innovations; the low level of science development; and the lack of new ideas. Based on the statistical informa- tion obtained from the Federal State Statistics Service, the key barriers to the implementation of innovations in production in Russia in 2014 have been determined (Fig. 4). As presented in Fig. 4, the most serious impediments when building an innovation economy in modern Russia were the lack of financing for science, the complexity of the commercialization of innovations, and the lack of necessary investments to implement innovations. This is, again, clearly reflected in Figs. 5 to 7.

As evidenced in Fig. 5, the number of innovational enterprises in Russia has declined by $20 \%$ over the past two decades, and, as presented in Fig. 6, the share of investment in financing scientific research constituted less than $1 \%$ over the period of 2011 to 2014 . Fig. 7 indicates that investments in the implementation of innovations in Russia increased between 1992 and 2013 but then decreased in 2014, revealing a negative tendency.

Based on the determined problems, the most prescriptive strategies for the development of innovational activities in modern enterprises to overcome global economic problems are as follows:

- provide favorable conditions for the creation of innovations in developing countries;

- provide favorable conditions for the commercialization of innovations in developing countries; 


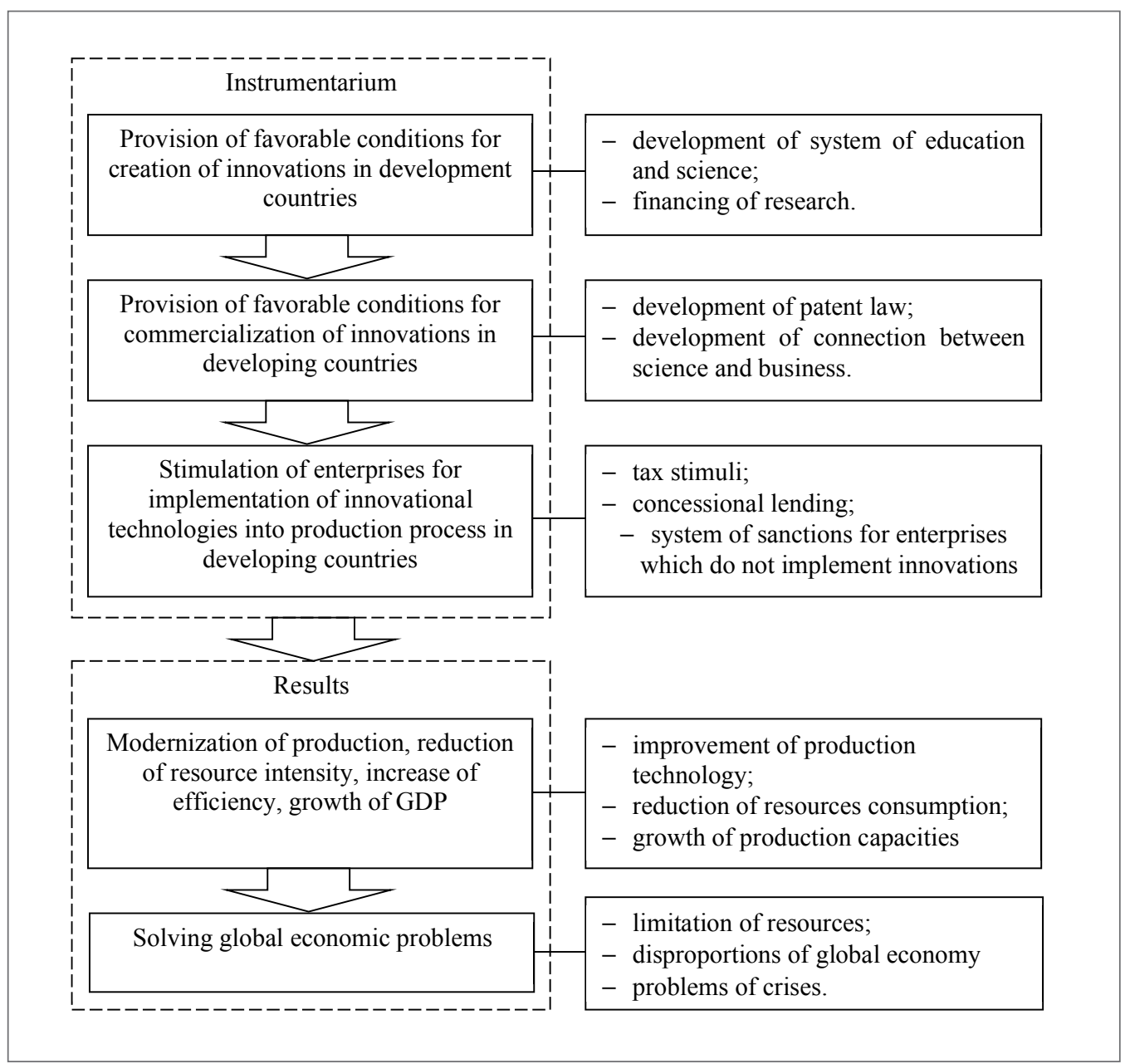

Figure 8. Algorithm of the innovational development of the modern global economy

- stimulate enterprises to implement innovational technologies in the production processes in developing countries.

To actualize these strategies, this research offers a proprietary mechanism for innovational development in the modern global economy, as presented in Fig. 8.

\section{Conclusion}

Thus, as a result of the conducted research, the offered hypothesis was proven and, by referencing the problems of limited resources, disproportionate economic growth, and crises in the global economy, it was sub- stantiated that the development of innovations is a perspective tool for solving global economic problems.

Innovations lead to improvements in the production process such that the consumption of resources decreases and the volume of manufactured goods increases, which leads to solving the problem of limited resources. The implementation of innovations in production at the enterprise level in the least developed countries stimulates their economic development and reduces the level of differentiation among countries in the global economy.

Under the conditions of recession, the economy does not develop, and economic growth stagnates. Accord- 
ingly, innovations create the stimulus for the development of the global economy, which ensures that the global economic crisis is overcome and solves the problem of the cyclic development of the global economy.

The most serious problems affecting the building of an innovational economy in Russia are the lack of financing for science, the complexity of the commercialization of innovations, and the lack of investments necessary to implement innovations.

To remove these barriers and build an innovation economy, this research offers an algorithm for the innovational development of a modern global economy that stimulates the increase of innovational activity in developing countries and the solving of global economic problems.

This research is built on the study of the role of innovation in solving three large economic problems that include the totality of global issues. Accordingly, this predetermines the limitations of the results of the research based on the problems chosen for analysis.

Therefore, it is expedient to conduct further research in this sphere to determine the role of innovations in solving global economic problems using the examples of other negative phenomena in the global economy, particularly the examples of the problems of ecological security and military threats to the global economy.

\section{References}

Al Mamun, M., \& Sohag, K. (2015). Revisiting the dynamic effect of foreign direct investment on economic growth in LDCs. International Journal of Economic Policy in Emerging Economies, 8(2), 97-118.

Aytaç, I. A., Rankin, B. H., \& İbikoğlu, A. (2015). The social impact of the 2008 global economic crisis on neighborhoods, households, and individuals in Turkey. Social Indicators Research, 124(1), 1-19.

Bhanumurthy, N. R., \& Singh, P. (2013). Financial sector development and economic growth in Indian states. International Journal of Economic Policy in Emerging Economies, 6(1), 47-63.

Bozkurt, Ö. G., Erdem, C., \& Ero冈lu, I. (2015). Identifying the factors affecting the economic growth of oil-producing countries. International Journal of Trade and Global Markets, 8 (2), 97-111.

Capello, R., Caragliu, A., \& Fratesi, U. (2015). Global trends and the economic crisis: Future alternative European growth strategies. Technological Forecasting and Social Change, 98, 120-136.
Caporale, G.M., \& Spagnolo, N. (2012). Stock market, economic growth and EU accession: Evidence from three CEECs. International Journal of Monetary Economics and Finance, 5(2), 183-191.

Coccia, M. (2015). General sources of general purpose technologies in complex societies: Theory of global leadership-driven innovation, warfare and human development. Technology in Society, 42, 199-226.

Donate, M. J., Peña, I., \& Sánchez de Pablo, J. D. (2016). HRM practices for human and social capital development: Effects on innovation capabilities. The International Journal of Human Resource Management, 27(9), 928-953.

Filinova, N. V., Filinov, V. P., Pogodina, O. N., Lunev, V. A., \& Luneva, E. V. (2015). The socio-economic foundations of the development of contemporary economic innovations. Asian Social Science, 11(6), 250-260.

Galbraith, J. K. (2015). Inequality and instability: A study of the world economy just before the great crisis. Inequality and Instability: A Study of the World Economy Just Before the Great Crisis, Oxford, UK: Oxford University Press.

Gehringer, A. (2014). Financial liberalisation, financial development and productivity growth: An overview. International Journal of Monetary Economics and Finance, 7(1), 40-65

Gerards, J. (2015). The ecthr's response to fundamental rights issues related to financial and economic difficulties: The problem of compartmentalisation. Netherlands Quarterly of Human Rights, 33(3), 274-292.

Grigoreva, E. A. (2015). Problems of institutional provision of the state's economic security. Mediterranean Journal of Social Sciences, 6(3), 499-503.

Grinin L., Devezas T., \& Korotayev A. (2012). Kondratieff's Mystery. Kondratieff Waves. In L. E. Grinin, T. C. Devezas, \& A. V. Kortayev (Eds.), Kondratieff waves: Dimensions and perspectives at the dawn of the $21^{\text {st }}$ century (pp. 5-22). Volgograd: Uchitel.

Gubaidullina, T. N. (2015). Systemic approach in the study of problems of territories's sustainable ecological and economic development. Mediterranean Journal of Social Sciences, 6 (1S3), 232-236.

Guttmann, R. (2015). Chronic macro-economic and financial imbalances in the world economy: A meta-economic view. Revista de Economia Politica, 35(2), 203-226. 
Heinrich, K., Kobayashi, Y., \& Bryant, K. A. (2016). Public opinion and foreign aid cuts in economic crises. World Development, 77, 66-79.

Hieronymi, O. (2016). The crisis of international finance, the Eurozone and economic growth. In S. P. S. Rossi, \& R. Malavi (Eds.), Financial crisis, bank behaviour and credit crunch (pp. 3-18). Berlin: Springer.

Jahfer, A., \& Inoue, T. (2014). Financial development, foreign direct investment and economic growth in Sri Lanka. International Journal of Economic Policy in Emerging Economies, 7(1), 77-93.

Kolychev, V. D., Prokhorov, I. V. (2015). Conception, technology and methods of development of university system of innovation projects commercialization based on effectuation. Asian Social Science, 11(8), 44-51.

McMaster, R. (2015). The "illusion" or "paradigm blindness" of economics: Ethical challenges to economic thought from the financial crisis. In T. H. Jo \& F. S. Lee (Eds.), Marx, Veblen, and the Foundations of Heterodox Economics: Essays in Honor of John F. Henry (pp. 155-175). London, UK: Routledge.

Melnik, M. S., Orlov, L. F., Bondarenko, A. V., Melnik, E. D.,Grekova, K. P. (2015). The Problems of Modern Economic Development: The Fundamental Mechanics. Mediterranean Journal of Social Sciences, 6(3), 646-653.

Ng, B. K., Kanagasundram, T., Wong, C. Y., Chandran, V. G. R. (2015). Innovation for inclusive development in Southeast Asia: The roles of regional coordination mechanisms. The Pacific Review, 2(1), 1- 30.

Omelchenko, K. Y. (2015). Model for economic indicators forecasting with a dual problem. Actual Problems of Economics, 164(2), 437-441.

Pogodaeva, T. V., Zhaparova, D. V., Rudenko, D. Y., Skripnuk, D. F. (2015). Innovations and socioeconomic development: Problems of the natural resources intensive use regions. Mediterranean Journal of Social Sciences, 6(1), 129-135.

Popkova, E. G, Zubakova, N. N., Bogdanov, D. V., Yakovleva, E. A, Nebesnay, A. Y. (2013). Measurement of economic growth as a factor of development of strategies of economic transformation. World Applied Sciences Journal, 25(2), 264-269.
Popkova, E. G., Yurev, V., Stepicheva, O., Denisov, N. (2015). Transformation and concentration of intellectual capital as a factor of economic growth in the modern economy. Regional and Sectoral Economic Studies, 15(1), 53-60.

Rodriguez, A., Turmo, J., \& Vara, O. (2014). Financial crisis and the failure of economic theory. Abington, UK: Routlege.

Rosstat (2015). Scientific research and innovations. Russia in numbers. 2015: Bulletin of Rosstat. Retrieved from Rosstat. (2015). Russia in numbers. Scientific research and innovations 2015: Bulletin of Rosstat. Retrieved from http://www.gks.ru/ free_doc/doc_2015/rusfig/rus-15.pdf

Rumyantsev, A. A. (2015). Science and innovation space of a macroregion: Prospects of innovative territorial development. Studies on Russian Economic Development, 26(4), 379-387.

Turriago-Hoyos, A., Thoene, U., Bernal-Torres, C., Alfonso-Lizarazo, E. (2015). Product innovation, research and development and technology acquisition: A case study of the industrial sector in Colombia. Institutions and Economies, 7(2), 85-119.

Vasin, S. M., Gamidullaeva, L. A. (2015). Development a basic model of the innovation system. Review of European Studies, 7(11), 175-183.

Visser, T. A. W., Ohan, J. L., Enns, J. T. (2015). Temporal cues derived from statistical patterns can overcome resource limitations in the attentional blink. Attention, Perception, and Psychophysics, 77(5), 1585-1595.

Waisová, Š. (2013). Od hrozby k přiležitosti: Vede nedostatek environmentálních zdrojů ke spolupráci? [From Threat to opportunity: Does a lack of environmental resources lead to cooperation?]. Mezinarodni Vztahy, 48(3), 32-61.

Yegireddy, N. K., Panda, S., Rout, U. K., Bonthu, R. K. (2015). Selection of control parameters of differential evolution algorithm for economic load dispatch problem. In L. C. Jain, H. S. Behera, J. K. Mandal, \& D. P. Mohapatra (Eds.), Computational Intelligence in Data Mining (Vol. 3, pp. 251260). New Delhi: Springer India.

Zhao, X., Jiang, X., Li, Z. (2015). The impact of the economic crisis on the financial performance of multinational corporations. International Review of Economics and Finance, 37, 55-68. 